\title{
The biosonar of the boto: evidence of differences among species of river dolphins (Inia spp.) from the Amazon
}

\author{
Jéssica F Melo ${ }^{\text {Corresp., } 1,2}$, Thiago S O Amorim ${ }^{1,3}$, Mariana Paschoalini ${ }^{1,2,3}$, Artur Andriolo ${ }^{1,3}$ \\ 1 Laboratório de Ecologia Comportamental e Bioacústica - LABEC, Universidade Federal de Juiz de Fora, Juiz de Fora, Minas Gerais, Brazil \\ ${ }^{2}$ Grupo de Pesquisa em Mamíferos Aquáticos Amazônicos, Mamirauá Sustainable Development Institute, Tefé, Amazonas, Brazil \\ 3 Instituto Aqualie, Juiz de Fora, Minas Gerais, Brazil \\ Corresponding Author: Jéssica F Melo \\ Email address: jessica.melo@mamiraua.org.br
}

Echolocation clicks can reflect the anatomy of the vocalizing animal, enabling the distinction of species. River dolphins from the family Iniidae are formally represented by one species and two subspecies (Inia geoffrensis geoffrensis and I. g. humboldtiana). Additionally, two other species have been proposed (I. boliviensis and I. araguaiaensis) regarding its level of restricted distribution and morph-genetics differences. For the Committee on Taxonomy of the Society for Marine Mammalogy, the specific status of the proposed species relies on further knowledge on morphology, ecology, and genetics. Given that species-specific status is required for conservation efforts, we described and compared the echolocation clicks of Inia spp., searching for specific differences on their vocalizations. The sounds were captured with a Cetacean Research ${ }^{\mathrm{TM}} \mathrm{C}$ C54RS $(+3 /-20 \mathrm{~dB}$, - 185dB re: $1 \mathrm{~V} / \mu \mathrm{Pa}$ ) in Guaviare River (Orinoco basin), Madeira River (Madeira basin), Xingu River (Amazon Basin), and Araguaia River (Tocantins-Araguaia basin). We found significant differences in all analyzed parameters (peak frequency, $3 \mathrm{~dB}$ bandwidth, $10 \mathrm{~dB}$ bandwidth and inter-click interval) for all species and subspecies. Differences in acoustical parameters of clicks are mainly related to the animal's internal morphology, thus this study may potentially support with information for the species-level classification mostly of I. araguaiaensis (the Araguaian boto). Classifying the Araguaian boto separately from $I$. geoffrensis has important implications for the species in terms of conservation status, since it is restricted to a highly impacted river system. 
1

2

3

4

5

6

$7 \quad{ }^{1}$ Laboratório de Ecologia Comportamental e Bioacústica - LABEC, Universidade Federal de Juiz

8 de Fora, Juiz de Fora, Minas Gerais, Brazil

$9 \quad{ }^{2}$ Grupo de Pesquisa em Mamíferos Aquáticos Amazônicos, Mamirauá Sustainable Development

\section{The biosonar of the boto: evidence of differences among species of river dolphins (Inia spp.) from the Amazon}

Jéssica Fernandes de Melo ${ }^{1,2}$, Thiago Orion Simões Amorim ${ }^{1,3}$, Mariana Paschoalini Frias $^{1,2,3}$, Artur Andriolo ${ }^{1,3}$

Institute, Tefé, Amazonas, Brazil

${ }^{3}$ Instituto Aqualie, Juiz de Fora, Minas Gerais, Brazil

Corresponding Author:

Jéssica Fernandes de Melo

Estrada do Bexiga 2584, Fonte Boa, Tefé, Amazonas, 69470-000, Brasil

Email address: jessica.melo@mamiraua.org.br 


\section{Abstract}

26 Echolocation clicks can reflect the anatomy of the vocalizing animal, enabling the distinction of

27 species. River dolphins from the family Iniidae are formally represented by one species and two 28 subspecies (Inia geoffrensis geoffrensis and I. g. humboldtiana). Additionally, two other species have

29 been proposed (I. boliviensis and I. araguaiaensis) regarding its level of restricted distribution and

30 morph-genetics differences. For the Committee on Taxonomy of the Society for Marine Mammalogy,

31 the specific status of the proposed species relies on further knowledge on morphology, ecology, and

32 genetics. Given that species-specific status is required for conservation efforts, we described and

33 compared the echolocation clicks of Inia spp., searching for specific differences on their vocalizations.

34 The sounds were captured with a Cetacean Research Tм C54XRS (+3/-20dB, - 185dB re: $1 \mathrm{~V} / \mu \mathrm{Pa})$ in

35 Guaviare River (Orinoco basin), Madeira River (Madeira basin), Xingu River (Amazon Basin), and

36 Araguaia River (Tocantins-Araguaia basin). We found significant differences in all analyzed

37 parameters (peak frequency, $3 \mathrm{~dB}$ bandwidth, 10dB bandwidth and inter-click interval) for all species

38 and subspecies. Differences in acoustical parameters of clicks are mainly related to the animal's internal

39 morphology, thus this study may potentially support with information for the species-level

40 classification mostly of $I$. araguaiaensis (the Araguaian boto). Classifying the Araguaian boto

41 separately from I. geoffrensis has important implications for the species in terms of conservation status,

42 since it is restricted to a highly impacted river system. 


\section{Introduction}

49 The biosonar of odontocetes (Cetartiodactyla: Odontoceti) is a complex system for navigation and

50 hunting. Through the analysis of echolocation clicks, it is possible to distinguish dolphin species, since

51 the characteristics of the sound produced by the animal depend on the anatomy of its skull and organs

52 responsible for sound production (Lilly \& Miller, 1961; Norris, 1968, 1975; Norris et al., 1971). The

53 sound is reflected in different materials inside the animals' head, generating a set of several pulse paths

54 outside the axis with the spectral properties specific to the species (Baumann-Pickering et al., 2010).

55 Internal pulse reflections can reveal the anatomy of the vocalizing animal, mainly through spectral

56 peaks that are dependent on the morphology of the skull, and therefore show a specific aspect of the

57 species (Soldevilla et al., 2008). Efforts are being made to discriminate free-range marine cetacean

58 species through their clicks, mainly in response to the increasing use of passive acoustic monitoring

59 (Madsen et al., 2005; Zimmer et al., 2005; Hildebrand et al., 2015; Amorim et al., 2019). Several studies

60 have already shown that the frequency parameters of clicks are different within odontocetes. Porpoises

61 can be distinguished at the subfamily level by peak frequency and time duration of their clicks

62 (Kamminga et al., 1996); Neophocaena phocaenoides (finless porpoise) can be distinguished from

63 Lipotes vexillifer (baiji) and Tursiops truncatus (bottlenose dolphins) by the frequency parameters of

64 their clicks (Akamatsu et al., 1998); Phocoena phocoena (harbor porpoise) and Pseudorca crassidens

65 (false killer whale) clicks are distinguishable from four species of dolphins based on peak frequency

66 and click duration (Nakamura and Akamatsu, 2003); Grampus griseus (Risso's dolphins) and 
67 Lagenorhynchus obliquidens (Pacific white-sided dolphins) can be distinguished to species level by

68 the frequency values of the spectral peaks and notches (Soldevilla et al., 2008).

69 River dolphins are a polyphyletic group morphologically and phylogenetically distinct from marine 70 dolphins, only found in northern South America and the subcontinent of Asia (Hamilton et al., 2001;

71 Reeves \& Martin, 2009) and its habitats are overlapped by many anthropogenic stressors (Reeves \&

72 Leatherwood, 1994; Trujillo et al., 2010). These mammals share a long and independent evolutionary

73 history as a highly modified taxon, having more autapomorphies than shared characters useful for 74 determining their affiliations (Messenger, 1994). Endemic to the Amazon, the family Iniidae are 75 formally represented by two subspecies: Inia geoffrensis geoffrensis in the Amazon basin and I. $g$. 76 humboldtiana in the Orinoco basin (both subspecies named here as Amazon river dolphin or boto).

77 Additionally, two other species have been proposed: I. boliviensis (Bolivian boto) in the Madeira basin 78 and I. araguaiaensis (Araguaian boto) in the Araguaia-Tocantins basin (Pilleri \& Gihr, 1977; Best \& 79 da Silva, 1989; Hrbek et al., 2014). All lineages from the genus Inia are geographically separated 80 through rapids and waterfalls among river basins, although some animals of the lineage I. boliviensis 81 manage to cross the barrier that separates them from I. g. geoffrensis in the Madeira River, resulting in 82 the formation of a group of hybrids biologically distinct from the species of origin (Gravena et al., 83 2014; 2015). Such hybrid zone is also identified for the proposed species I. araguaiaensis and the $I$. 84 geoffrensis in the region of the Marajó Bay - Tocantins' River mouth (J. Farias \& G. Melo-Santos, 85 2020, pers. comm.).

86 There are few morphological differences among the proposed species - the number of teeth and the 87 size of the rostrum are pointed out as external characteristics that distinguish them (Pilleri \& Gihr, 88 1977; Hamilton et al., 2001; Banguera-Hinestroza et al., 2002; Ruiz-García, Banguera \& Cardenas, 89 2006; Hrbek et al., 2014), and the biggest differences are molecular. Given that the morphological 
90 differences are subtle, the Araguaian and Bolivian botos are yet to be recognized by the Committee on

91 Taxonomy of the Society for Marine Mammalogy (Committee on Taxonomy, 2020). The Araguaian

92 boto is a sister species of the boto or Amazon river dolphin and presents even more distinct characters

93 when compared to the Bolivian boto (Hrbek et al., 2014).

94 Because of the morphological similarities among the lineages of Inia and the requirement of further

95 information to assess the conservation status, acoustics analysis emerges as a complementary tool for

96 the distinction among them that may support the evidences already published. We are not aware of

97 studies that describe the clicks of Bolivian and the Araguaian botos. Acoustics studies with river

98 dolphins are scarce when compared to marine dolphins. Therefore, our objective was to describe and

99 compare the acoustical parameters of Inia clicks among lineages. This comparison and the description

100 of the biosonar parameters of each lineage can improve the knowledge on their biology, in addition to

101 being the first step towards monitoring of the species using acoustics methods.

102

103 Material \& Methods

104 Study area

105 Data collection was carried out in four hydrographic basins (Fig. 1). The subspecies I. $g$. 106 humboldtiana was sampled in the Guaviare River, Orinoco basin, Colombia; I. g. geoffrensis in the 107 Xingu River, Amazon basin, Brazil; I. araguaiaensis in the Araguaia River (Cantão State Park), 108 Tocantins-Araguaia basin, Brazil; and I. boliviensis in the Madeira River, Amazon basin, Brazil. Data 109 regarding I. boliviensis was sampled in the Madeira River within the artificial lake created between 110 two hydroelectric dams: the Jirau and the Santo Antônio Dams. This human enterprise was constructed 111 in a hybrid zone of I. boliviensis and I. geoffrensis, creating a barrier for individuals, drastically 112 breaking the genetic flow between populations (Gravena et al., 2014, 2015). Therefore, it was not 
113 possible to obtain specific data only for I. boliviensis, since it is impossible to differentiate species

114 visually. The sounds collected in the Madeira River were then attributed to I. boliviensis, I. g. 115 geoffrensis and hybrids.

116 The Guaviare River is a sinuous white-water river of the Orinoco basin, rising in the eastern 117 Colombian mountain range and flowing into the Orinoco River at the confluence with Inirida River. 118 River nutrient levels are low, there is rapid flow and sandy sediments (Medina \& Silva, 1990; Meade 119 \& Koehnken, 1991; Savage \& Potter, 1991). It is 1,350 km long, with a basin area of 112,522 km2, 120 flowing at 8,200 m³ (http://www.siatac.co/web/guest/region/hidrologia). The Xingu is a large clear121 water river of the Amazon basin, covering a drainage area of approximately $520,000 \mathrm{~km}^{2}$ and about 122 2,000 $\mathrm{km}$ in length with an average flow between 2,582 and 9,700 $\mathrm{m}^{3} / \mathrm{s}$ (Pettena et al., 1980; Latrubesse $123 \&$ Sinha, 2005). In its lower course, it presents a mosaic environment composed by rocky margins and 124 flooded forest (várzea) (Latrubesse \& Sinha, 2005). The Itamacará waterfall is the upper the limit of 125 the dolphins' distribution (M. Paschoalini, 2020, pers. comm.). The Madeira is a wide and muddy126 white-water river, and one of the main tributaries in the Amazon river basin extending to three countries 127 with 51\% in Brazil, 42\% in Bolivia and 7\% in Peru, where the Madre de Dios River, a tributary of the 128 Mamoré River, is born (Guyot, 1993). Along the Madeira River, there are 18 rapids and waterfalls that 129 extend a distance of $290 \mathrm{~km}$ (Cella-Ribeiro et al., 2013), and most of them are currently submerged by 130 the Santo Antônio and Jirau hydroelectric dam reservoirs (Gravena et al., 2015). The Araguaia River 131 is the major tributary of the Tocantins-Araguaia basin. It is a low depth-black-water river 2,600 km in 132 length (Brazilian Ministry of the Environment, 2006). In the hydrographic basin of the Araguaia River, 133 there is a protected area of 90,000 hectares created by the Brazilian government in 1998, the Cantão 134 State Park (Seplan, 2001). With approximately 880 lakes and many meanders and natural channels, the 
135 park comprises two dominant biomes, the Amazon forest in the west and the Cerrado (Brazilian

136 savanna) in the east, bounded in the southwest by the Bananal Island region (Seplan, 2016).

\section{Data collection}

139 In the Guaviare River, sound samples were collected during 6 days in March 2016, at the middles 140 reaches of this river near the Mapiripã rapids (lat $2^{\circ} 52^{\prime} 54.4044^{\prime \prime} \mathrm{S}$; long $72^{\circ} 10^{\prime} 29.2656^{\prime \prime} \mathrm{W}$ ). In the 141 Madeira River data were collected along the dam's reservoirs, mainly at the Jaci-Paraná municipality 142 (lat 9 11' 15.9" S; long 9० 11' 15.9" S), during a 4-day effort in October 2014. In the Xingu River data

143 were collected near the Vitória do Xingu municipality and along the river margins up to Belo Monte

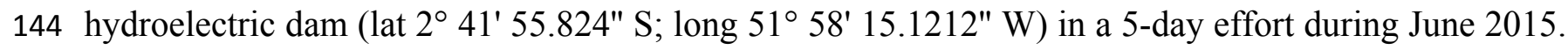
145 Finally, the sound samples in the Araguaia River were collected inside the Cantão State Park (lat $9^{\circ}$ $14618^{\prime} 47.88^{\prime \prime} \mathrm{S}$; long $49^{\circ} 56^{\prime} 37.32^{\prime \prime} \mathrm{W}$ ) in a 6-day effort in June 2017 . The permit for fieldwork inside the 147 Cantão State Park was approved by the Tocantins State Government, Instituto Natureza do Tocantins 148 - Naturantins (permit number 1497-2017).

149 For data collection, a small outboard vessel was used for transportation and dolphin observations.

150 At the presence of a group of dolphins, the engine of the vessel was turned off and the hydrophone 151 placed in the water approximately 2 meters below the surface. The acoustic recording was done 152 opportunistically during the sighting of an animal or group of animals. The Xingu River is the only 153 sampled area where the distribution of Sotalia fluviatilis (tucuxi) overlaps with Inia sp. Therefore, data 154 collection took place after a visual search to ensure that no tucuxi was observed at the time of data 155 collection. The clear water of the Xingu River allows greater certainty that no tucuxi was close to the 156 botos during the recordings. 
157 Underwater sound emissions were captured using a Cetacean Research TM C54XRS hydrophone (+ $1583 /-20 \mathrm{~dB},-185 \mathrm{~dB}$ re: $1 \mathrm{~V} / \mu \mathrm{Pa}$, sampling rate of $400 \mathrm{kHz}$ ) of passive capture mobile. The captured 159 sounds were transferred to a Daq/3000 Series digitizer card, and the files were recorded in .bin format 160 and later converted to .wav (frequency response of $200 \mathrm{kHz} / 24 \mathrm{bits}$ ).

161

162 Data analysis

163 The acoustic analyses were performed using the Raven Pro software 1.5 (Hamming window of 256

164 points of FFT with 50\% overlap, Cornell Laboratory of Ornithology, New York) and MatLab R2014A

165 (Mathworks, Natick, MA). Recordings with interference and loud noise were discarded, to prevent

166 misclassification. The low frequency noise caused by water flow was filtered with a cut-off at $5 \mathrm{kHz}$

167 and the click trains were detected through visual analysis in Raven Pro software. Then, meta-data files

168 were created containing just one click train (Fig. 2). Next, we used a custom routine in MatLab R2014A

169 to compute the following parameters: peak frequency, signal bandwidths ( $3 \mathrm{~dB}$ and $10 \mathrm{~dB}$ ) and inter-

170 click intervals (ICI). Firstly, the custom routine plots the waveform for the user to choose a threshold

171 above which the eligible clicks have their spectrum and peak frequency calculated. Then, it computes

172 the higher and lower $3 \mathrm{~dB}$ and $10 \mathrm{~dB}$ power points for the final calculation of the bandwidths. The user

173 visually evaluates and chooses a different threshold for each click train. These parameters are the most

174 used in the literature to characterize and distinguish the clicks. Multiple overlapped click trains due to

175 the simultaneous vocalization by more than one animal were only used for frequency analyses and not

176 for the ICI computation.

177 Statistical analysis was conducted in R (R Core Team, 2015). Firstly, the descriptive statistics were

178 calculated for all parameters including maximum and minimum values, mean, standard deviation,

179 median and interquartile range. Then, the Kruskal-Wallis test was applied to check if there is a 
180 difference among the 'species' and subspecies for all parameters analyzed. Subsequently, a Dunn-

181 Bonferroni post hoc method following the Kruskal-Wallis test was also performed to discriminate the

182 lineages (i.e. analyze each combination pair to verify the differences between them) only for the

183 frequency parameters of the clicks.

184 Then, Random Forest models were created to classify the lineages according to their echolocation 185 clicks (packages 'randomForest' and 'pROC') (version 3.4.3, R Core Team, 2015). Random Forest 186 models are a series of unpruned classification trees, with 500 bootstrap samples taken from the original 187 data set. Data not selected to build a tree were referred to as "out-of-bag" (OOB) and were used to 188 validate classification accuracy of the forest, estimating the error rate (Brieman, 2001; Liaw \& Wiener, 189 2002). Next, the importance of each variable (peak frequency, $3 \mathrm{~dB}$ and $10 \mathrm{~dB}$ bandwidths) was tested 190 with the mean decrease accuracy and Gini variable importance measure. This metric is based on a 191 weighted mean of the improvement of individual trees based on the inclusion of each variable as a 192 predictor. We used $80 \%$ of the data for training and $20 \%$ were for testing. Finally, Receiver Operating 193 Characteristic (ROC) curves were created in order to verify the classifying efficiency of the model by 194 the area under the curve (AUC). We choose a model performance acceptable when AUC $\geq 0.7$ (Swets, 195 2013).

196 In a first step of the classification analysis, the Random Forest model was used to classify only the 197 lineages I. araguaiaensis, I. g. geoffrensis and I. g. humboldtiana, because the 'species' I. boliviensis 198 could not be visually distinguished from I. g. geoffrensis and hybrids in the Madeira River. In a second 199 step, we ran a k-means clustering analysis (packages 'factoextra', 'cluster' and 'tidyverse') only for 200 the sampled animals in Madeira River (I. boliviensis, I. g. geoffrensis and hybrids) in order to verify if 201 the clicks could be grouped into clusters. This method is commonly used to automatically partition a 202 data set into $\mathrm{k}$ groups. It proceeds by selecting $\mathrm{k}$ initial cluster centers and then iteratively refining them 
203 (Wagstaff et al., 2001). We used the silhouette method to establish the optimal number of clusters

204 within Madeira River. We applied the Hubert index and D index as methods to determine the best 205 number of clusters, through the "NbClust" function (using: method = "kmeans") (package NbClust) 206 (Charrad et al., 2014). Then, we used the Random Forest model again, but herein considering the $\mathrm{k}$ 207 clusters and adding I. g. geoffrensis from the Xingu River to the analysis, in order to compare each 208 cluster to this species, as it is also presented at the Madeira River together with I. boliviensis and 209 hybrids.

210 Table 1 summarizes the data analyzed, with the number of click trains and clicks, the mean number 211 of animals during the recordings, the sampling effort and the minutes analyzed in each river.

212

\section{Results}

214 Inia araguaiaensis clicks showed the highest peak frequency value (mean $=49.0 \pm 12.0 \mathrm{kHz})$ and 215 I. g. humboldtiana the smallest (mean $=43.9 \pm 7.7 \mathrm{kHz}$ ). Both $10 \mathrm{~dB}$ and $3 \mathrm{~dB}$ bandwidths were higher 216 for I. boliviensis, I. g. geoffrensis and hybrids from the Madeira River (mean $=77.6 \pm 28.9 \mathrm{kHz}$ and $21733.8 \pm 20.1 \mathrm{kHz}$, respectively) and lower for I. g. geoffrensis on Xingu River (mean $=65.5 \pm 28.8 \mathrm{kHz}$ 218 and $24.3 \pm 14.8 \mathrm{kHz}$, respectively). I. g. geoffrensis showed the highest ICI value (mean $=68.9 \pm 35.5$ $219 \mathrm{~ms})$ and $I . g$. humboldtiana the smallest (mean $=13.8 \pm 7.4 \mathrm{~ms})$ (Table 2).

220 According to the Kruskal-Wallis test, there was a significant statistical difference among lineages

221 for all parameters analyzed ( $\mathrm{p}$-value $<0.05$ ). According to the post hoc test, the $10 \mathrm{~dB}$ bandwidth did 222 not show significant differences for I. araguanaensis and I. g. humboldtiana, the $3 \mathrm{~dB}$ bandwidth did 223 not show significant differences for I. araguaiaensis and Inia spp. (I. boliviensis, I. g. geoffrensis and 224 hybrids), and the peak frequency was not significant different comparing I. g. humboldtiana with Inia 225 spp. and I. g. geoffrensis. In table 3, it is possible to see all the other pairs compared that had a 
226 significant difference in each analyzed parameter (numbers in bold). The boxplot of each analyzed

227 parameter of the clicks shows the differences among the lineages (Fig. 3).

228 Random Forest model showed low misclassification among the lineages analyzed - minimum of $9 \%$

229 between I. g. geoffrensis and I. g. humboldtiana and maximum of 23\% between I. g. geoffrensis and I.

230 araguaiaensis (Table 4) - and a clear separation of I. araguaiaensis, I. g. geoffrensis and I. g.

231 humboldtiana by their echolocation clicks (Fig. 4). The general accuracy of the model was of 70\%, and

232 the balanced accuracy for I. araguaiaensis was of $75 \%$, for $I$. g. geoffrensis was $69 \%$ and for $I$. $g$.

233 humboldtiana was $81 \%$. The parameters that most contributed to the model were peak frequency and

$2343 \mathrm{~dB}$ bandwidth. Random Forest classifier showed high goodness of fit with area under the curves of

2350.897 for I. g. humboldtiana, 0.837 for I. araguaiaensis and 0.793 for I. g. geoffrensis.

236 Regarding data analysis of the Madeira River (Inia spp.), we found three clusters as an optimal

237 number of clusters by the silhouette method (Fig. 5). This may be due to the presence of three groups

238 of animals in the area where we collected data - I. boliviensis, I. g. geoffrensis and hybrids. We termed

239 the clusters as Ispp1, Ispp2 and Ispp3, as we could not certainly assign them to I. g. geoffrensis, I.

240 boliviensis or hybrids. The Random Forest analysis, performed with I. g. geoffrensis (Igg) from the

241 Xingu River together with the clusters, showed that Igg had $64 \%$ of correct classifications and $27 \%$ of

242 misclassification with Ispp1, which classified correctly in $79 \%$ of the data. Ispp 2 had $80 \%$ of correct

243 classifications and 19\% of error with Igg. Ispp3 had 85\% of correct classification and 13\% of error

244 with Igg (Table 4). The general accuracy of the model was $76 \%$ and the balanced accuracies were $69 \%$

245 for Igg, 85\% for for Ispp1, 92\% for Ispp2 and 97\% for Ispp3. The classification tree is represented in

246 Figure 6. The parameters that most contributed to the model were peak frequency and 10dB bandwidth.

247 The ROC curves of this classification showed the goodness of fit of the model with areas greater than

2480.809 (Fig. 6). 


\section{Discussion}

\section{Characterization of the echolocation clicks}

252 In the past few years, a greater effort has been made to understand the acoustic behavior of Amazon 253 river dolphins (e.g. Caldwell, Caldwell \& Evans, 1966; Kamminga et al., 1993; Ding, Würsig \& 254 Leatherwood, 2001; Podos, Da Silva \& Rossi-Santos, 2002; Diazgranados \& Trujillo, 2002; May255 Collado \& Wartzok, 2007; Yamamoto et al., 2015; Ladegaard et al., 2015, 2017; Amorim et al., 2016; 256 Melo-Santos et al., 2019, 2020), but there are still no studies on the echolocation clicks of I. boliviensis 257 and I. araguaiaensis. Most of the studies on boto's clicks (e.g. Ladegaard et al., 2015, 2017; Yamamoto 258 et al., 2015) describe only clicks recorded on the animal's body axis, unlike the present study, where 259 we analyzed both on and off-axis clicks. On-axis clicks may not accurately represent the complete set 260 of clicks that are acquired during passive acoustic monitoring of odontocetes (Soldevilla et al., 2008).

261 Au, Floyd \& Haun (1978) established that off-axis click durations are longer, usually due to multiple

262 paths of the initial click pulse, and suggested that the multiple paths are due to reflections within the 263 head, the external environment, or a combination of the two. Amorim et al. (2019) discriminated eight 264 delphinid species by their off-axis echolocation clicks and found that these pulsed sounds are better 265 when comparing to the tonal sounds in discriminating species.

266 The farther the click is recorded off the animals' axis, both horizontally and vertically, the lower 267 frequency will be the strongest peak in the spectra $(\mathrm{Au}, 1980)$. Here, we found a mean peak frequency 268 of $45.5 \mathrm{kHz}$ for I. geoffrensis' clicks, as well as Kamminga \& Wiersman (1981), that found I. 269 geoffrensis' echolocation clicks at $40-80 \mathrm{kHz}$. However, our results showed peak frequency values 270 dropping almost by half comparing to $96 \mathrm{kHz}$ found by Ladegaard et al. (2017) and $82 \mathrm{kHz}$ by 271 Yamamoto et al. (2015). The river dolphin Sotalia fluviatilis (tucuxi), which overlaps its area of 
272 occurrence with $I$. geoffrensis, produces clicks with a peak frequency around $80-90 \mathrm{kHz}$ (Kamminga

273 et al., 1993; May-Collado \& Wartzok, 2010). The presence of this animal may be a bias in the study of

274 the bioacoustics of the boto. In the current study, tucuxi's area of occurrence overlaps with $I$.

275 geoffrensis only in the Xingu River, but care was taken to visually detect the presence of animals at the

276 time of recording. In addition, different data collection equipment can also influence the result.

277 Therefore, we verified the need for standardization in studies and further investigations among

278 populations of river dolphins throughout the Amazon.

279 In relation to other species of river dolphins around the world, the Lipotes vexillifer (baiji) produces

280 clicks with peak frequency between 50 and $100 \mathrm{kHz}$ (Akamatsu et al., 1998), the Pontoporia blainvillei

281 (franciscana dolphin) produces high frequency clicks (+/- 139 kHz, Melcón, Failla, \& Iñíguez, 2012),

282 and the Platanista gangetica gangetica (Indus river dolphin) has an average peak frequency of $58.8 \pm$

$2836.8 \mathrm{kHz}$ (Jensen et al., 2013). Both the Indus river dolphin and the boto face challenges to locate food

284 and move around in an acoustic habitat with high levels of reverberation and attenuation. Vocalizing

285 in lower frequencies can guarantee that the acoustic information is transmitted reliably, increasing the

286 active space of the signal under conditions of greater attenuation and dispersion (Hamilton et al., 2001).

287 Previous studies partly support this hypothesis that the peak frequency of Amazon river dolphin clicks

288 that inhabited flooded forests was slightly lower compared to the Sotalia fluviatilis's clicks, species

289 that does not go into the flooded forests of the Amazon (Yamamoto et al., 2015).

290

291 Differences in the species and subspecies of the genus Inia

292 All the parameters of the clicks analyzed in this work (ICI, peak frequency, 3dB and 10dB

293 bandwidth) were significantly different between lineages of the genus Inia. However, we only use the

294 parameters in the frequency domain, since the ICI depends on the behavioral context of the animal 
295 (Madsen et al., 2005; Baumann-Pickering et al., 2010). The lineages of genus Inia are morphologically

296 distinguishable through cranial measurements and number of teeth (Hamilton et al., 2001; Hrbek et al., 297 2014). The skull characteristic can influence the sound production path (Walker et al., 1986). These 298 dolphins are not visually distinguishable, and the ability to distinguish them acoustically could offer a 299 view of the differences in the biology of each lineage.

300 The Araguaian boto, a species not yet confirmed by the Committee on Taxonomy of the Society for 301 Marine Mammalogy, had all the click frequency parameters significantly different from $I . g$. 302 geoffrensis. The misclassification of sounds between the two lineages according to the Random Forest 303 analysis, was also low ( $18 \%$ and $23 \%$ ), showing a potentially useful evidence of taxonomic distinction.

304 Due to the aforementioned factors of association of the animal's skull shape in relation to the click 305 frequency characteristics (Lilly \& Miller, 1961; Norris, 1968, 1971, 1975), in addition to studies that 306 classify species through the echolocation clicks (e.g. Baumann-Pickering et al., 2010; Amorim et al., 307 2019), our results may be another evidence that there are differences between both lineages, reinforcing 308 the classification of I. araguaiaensis as a distinct species from I. geoffrensis.

309 There was a greater difference in frequency between different 'species' than between individuals of 310 the same species, since the subspecies $I$. g. geoffrensis and I. g. humboldtiana did not show significant 311 differences in peak frequency of the clicks according to the post hoc test. However, the $3 \mathrm{~dB}$ and $10 \mathrm{~dB}$ 312 bandwidths were significantly different between subspecies, showing a discriminating aspect between 313 their echolocation clicks. Additionally, I. g. humboldtiana had the higher rate of correct classification $314(74 \%)$ according to the Random Forest model. Efforts are being made to obtain more information on 315 the possible classification of I. g. humboldtina as a new species, or at least as a separate evolutionary 316 unit from I. g. geoffrensis (Trujillo \& Diazgranados, 2004; F. Trujillo, 2020, pers. comm.). Our results 317 can assist in the classification of this dolphins. 
The clusters generated by k-mean analysis showed the possible existence of three distinct groups of

319 sounds collected in the Madeira River. This data was collected in a hybrid zone of I. g. geoffrensis and

320 I. boliviensis. It is possible that these clusters are associated with each of these animals. The formation

321 of an overlap zone between I. boliviensis and I. g. geoffrensis is natural and has not occurred recently

322 (Gravena et al., 2015; Farias \& G. Melo-Santos, 2020, pers. comm.), although it was forced by the

323 construction of the dams (Jirau and Santo Antônio hydroelectric plants). The hybrid population of Inia

324 sp. would be biologically distinct from the species that originated it since it is expected that hybrid

325 animals will also develop specific characteristics, which was confirmed through our cluster results,

326 supporting the possible existence of three distinct acoustic groups in this area. These findings support

327 the hybridization hypotheses. In order to have a greater degree of certainty about the animals of the

328 Madeira River, it is necessary to record in a region where only I. boliviensis is present, i.e. above the

329 Jirau hydroelectric plant near Abunã, where the occurrence of I. geoffrensis is already ruled out 330 (Gravena et al., 2015).

331 Automatic click classifiers have not yet been tested for river dolphins in South America. We present

332 evidence that the clicks of Inia sp. have specific and promising characteristics to be automatically

333 detected for the use in passive acoustic monitoring. However, even though we have potentially useful

334 evidence of taxonomic distinction, the misclassification between the lineages would substantially limit

335 the accuracy or applicability of acoustic monitoring. In addition, as lineages of Inia are geographically

336 separated, the key tasks for passive acoustic monitoring of river dolphins from Amazon will be low

337 error rates in achieving distinction from Sotalia fluviatilis and from non-cetacean noise sources.

338 Therefore, our results are preliminary and further investigation on a broader dataset is necessary.

340 Conservation 
341 Inia geoffrensis is classified as "endangered" on the IUCN Red List (da Silva \& Martin, 2018).

342 There is still no conservation status for I. boliviensis and I. araguaiaensis due to the lack of knowledge

343 on distribution range, population estimates, genetics, and threats for these species. Gomez-Salazar et

344 al. (2012) suggest independent status for geographically distinct populations of the Bolivian boto,

345 separated by different hydrographic basins (the upper Madeira River in Brazil, and the Itenez-Mamoré

346 river basin in Bolivia). The Araguaian boto (Inia araguaiaensis) appears as the most distinct from its

347 counterparts, with low levels of genetic diversity, in addition to the restricted distribution in a highly

348 fragmented riverine-scape, and possibly presenting low population numbers compared to the Amazon

349 boto (Hrbek et al., 2014; Paschoalini et al., 2020). Such evidences, summed with the lack of dedicated

350 studies to these lineages, are quite concerning.

351 All lineages of Amazon river dolphins are threatened by human activities, i.e. hydroelectric 352 constructions and conflicts with fisherman (Iriarte \& Marmontel, 2013; Pavanato et al., 2016; 353 Paschoalini et al., 2020). For the correct evaluation of the impacts of such threats on the 'species' or 354 populations, so as the proper formulation of conservationist actions and environmental policies, it is 355 advisable to assign the conservation status of the lineages based on the characters described in the 356 literature, its distribution and population numbers, and also the findings of the present study. If a species 357 is included in the IUCN red list, for example, it will be prioritized on conservation studies. The results 358 of the present study have shown to be useful as a tool for the differentiation among lineages of genus 359 Inia, contributing to the few morphological differences. Classifying I. araguaiaensis separately from 360 I. geoffrensis, specially, is substantially important due to the pressure of human activities in the 361 Tocantins-Araguaia river basin (mainly dams). Once classified, further studies on distribution and 362 population estimation may provide greater knowledge about its conservation status, and thus provide 363 protective measures for the new species. 
364 Conclusion

365 Amazon river dolphins (Inia spp.) have shown species-specific acoustics properties in their clicks.

366 Their echolocation clicks had significant differences between lineages, thus acoustics approaches can

367 be an effective tool to differentiate Inia species. This study presents more evidence of differences

368 between the newly described I. araguaiaensis from I. geoffrensis. Our results may assist in the passive

369 acoustic monitoring of dolphins and possibly improve efforts and knowledge for I. g. humboldtiana.

370 However further studies are needed to analyze I. boliviensis separately, and to investigate inter- and

371 intra-species variations based on their acoustic parameters.

372

373

\section{Acknowledgments}

We are thankful to Santo Antônio Energia (Fauna Conservation Program in Madeira River); to Sete

375 Soluções e Tecnologia Ambiental Ltda, in the person of Eduardo Sábato; to Danielle Lima (research 376 coordinator of the Aquatic Mammal Monitoring Program in Madeira River); to Norte Energia (Aquatic 377 Mammal Monitoring Program in Xingu River); to LEME Engenharia Ltda; to Omacha Fundation, in 378 the person of Fernando Trujillo; to Joice Farias and Gabriel Melo-Santos for the personal comments; 379 to Adailton Glória (Cantão State Park manager); to Samara Bezerra and Bruna Pagliani for the help in 380 the fieldwork; and to Anne Landine for the conceptualization of the map.

\section{References}

383 Akamatsu T, Wang D, Nakamura K, Wang K. 1998. Echolocation range of captive and free384 ranging baiji (Lipotes vexillifer), finless porpoise (Neophocaena phocaenoides), and bottlenose 385 dolphin (Tursiops truncatus) . THE JOURNAL OF THE ACOUSTICAL SOCIETY OF AMERICA 386 104:2511-2516. DOI: 10.1121/1.423757. 
387 Amorim TOS, Andriolo A, Reis SS, dos Santos ME. 2016. Vocalizations of Amazon river

388 dolphins (Inia geoffrensis): characterization, effect of physical environment and differences between 389 populations . THE JOURNAL OF THE ACOUSTICAL SOCIETY OF AMERICA 139:1285-1293. 390 DOI: 10.1121/1.4943556.

391 Amorim TOS, de Castro FR, Moron JR, Duque BR, Di Tullio JC, Secchi ER, Andriolo A. 2019.

392 Integrative bioacoustics discrimination of eight delphinid species in the western South Atlantic 393 Ocean. PLOS ONE 14:1-17. DOI: 10.1371/journal.pone.0217977.

394 Au WWL, Floyd RW, Haun JE. 1978. Propagation of Atlantic bottlenose dolphin echolocation 395 signals. Journal of the Acoustical Society of America 64:411-422. DOI: 10.1121/1.382015.

Au WWL. 1980. Echolocation signals of the Atlantic bottlenose dolphin (Tursiops truncatus) in open waters. In: ANIMAL SONAR SYSTEMS. Springer US, 251-282. DOI: 10.1007/978-1-4684398 7254-7_10.

399 Banguera-Hinestroza E, Cárdenas H, Ruiz-García M, Marmontel M, Gaitán E, Vázquez R, 400 García-Vallejo F. 2002. Molecular identification of evolutionarily significant units in the Amazon 401 river dolphin Inia sp. (Cetacea: Iniidae). JOURNAL OF HEREDITY 93:312-322. DOI: 402 10.1093/jhered/93.5.312.

403 Baumann-Pickering S, Wiggins SM, Hildebrand JA, Roch MA, Schnitzler HU. 2010.

404 Discriminating features of echolocation clicks of melon-headed whales (Peponocephala electra), 405 bottlenose dolphins (Tursiops truncatus), and Gray's spinner dolphins (Stenella longirostris 406 longirostris). The Journal of the Acoustical Society of America 128:2212-2224. DOI: 407 10.1121/1.3479549.

408 Best RC, da Silva VMF. 1989. Amazon river dolphin, boto Inia geoffrensis (de Blainville, 1817). 409 In: Ridgway SH, Harrison R eds. Handbook of marine mammals. River dolphins and the larger 
410 toothed whales. Book 4. London, 1-23.

411 Brazilian Ministry of the Environment. 2006. Caderno da região hidrográfica do Tocantins412 Araguaia. Brasília, p.136.

413 Brieman L. 2001. Random forests. MACHINE LEARNING 45:5-32.

414 Caldwell MC, Caldwell DK, Evans WE. 1966. Sounds and behavior of captive Amazon

415 freshwater dolphin, Inia geoffrensis. CONTRIBUTIONS IN SCIENCE 108:1-24.

416 Cella-Ribeiro A, Torrente-Vilara G, Hungria DBDB, De Oliveira M. 2013. As corredeiras do rio 417 Madeira. In: Queiroz LJ, Torrente-Vilara G, Ohara WM, Pires T, Zuanon J, Doria CRC eds. Peixes 418 do rio Madeira. São Paulo, Brazil, 56-63.

419 Charrad M, Ghazzali N, Boiteau V and Niknafs A. 2014. NbClust: An R package for 420 determining the relevant number of clusters in a data set. JOURNAL OF STATISTICAL

421 SOFTWARE 61, 6.

422 Committee on Taxonomy. 2020. List of marine mammal species and subspecies. Society for 423 Marine Mammalogy. Available at https://marinemammalscience.org

424 da Silva VMF, Martin AR. 2018. Amazon River Dolphin. Encyclopedia of Marine Mammals:21425 24. DOI: 10.1016/b978-0-12-804327-1.00044-3.

426 Diazgranados MC, Trujillo F. 2002. Vocal repertoire of the freshwater dolphins Inia geoffrensis 427 and Sotalia fluviatilis in Colombia, South America . THE JOURNAL OF THE ACOUSTICAL 428 SOCIETY OF AMERICA 112:2400-2400. DOI: 10.1121/1.4779794.

429 Ding W, Würsig B, Leatherwood S. 2001. Whistles of boto, Inia geoffrensis, and tucuxi, Sotalia 430 fluviatilis. THE JOURNAL OF THE ACOUSTICAL SOCIETY OF AMERICA 109:407-411. DOI: $43110.1121 / 1.1326082$.

432 Dudgeon D. 1992. Endangered ecosystems: a review of the conservation status of tropical Asian 
433 rivers. HYDROBIOLOGIA 248:167-191. DOI: 10.1007/BF00006146.

434 Gomez-Salazar C, Trujillo F, Portocarrero-Aya M, Whitehead H. 2012. Population, density 435 estimates, and conservation of river dolphins (Inia and Sotalia) in the Amazon and Orinoco river 436 basins. MARINE MAMMAL SCIENCE 28:124-153. DOI: 10.1111/j.1748-7692.2011.00468.x.

437 Gravena W, da Silva VMF, da Silva MNF, Farias IP, Hrbek T. 2015. Living between rapids: 438 Genetic structure and hybridization in botos (Cetacea: Iniidae: Inia spp.) of the Madeira River, 439 Brazil. BIOLOGICAL JOURNAL OF THE LINNEAN SOCIETY 114:764-777. DOI:

440 10.1111/bij.12463.

441 Gravena W, Farias IP, da Silva MNF, da Silva VMF, Hrbek T. 2014. Looking to the past and the 442 future: Were the Madeira River rapids a geographical barrier to the boto (Cetacea: Iniidae)? 443 CONSERVATION GENETICS 15:619-629. DOI: 10.1007/s10592-014-0565-4.

444 Guyot JL. 1993. Le bassin du Rio Madeira à Villabella. In: Hydrogéochime des fleuves de 445 L'Amazonie Bolivienne. Paris: Collection Études et Thèses, 39-48.

446 Hamilton H, Caballero S, Collins AG, Brownell J. 2001. Evolution of river dolphins. Proceedings 447 of the Royal Society B: Biological Sciences 268:549-556. DOI: 10.1098/rspb.2000.1385.

448 Hildebrand JA, Baumann-Pickering S, Frasier KE, Trickey JS, Merkens KP, Wiggins SM, 449 McDonald MA, Garrison LP, Harris D, Marques TA, Thomas L. 2015. Passive acoustic monitoring 450 of beaked whale densities in the Gulf of Mexico. SCIENTIFIC REPORTS 5:1-15. DOI:

451 10.1038/srep16343.

452 Hrbek T, Da Silva VMF, Dutra N, Gravena W, Martin AR, Farias IP. 2014. A new species of river 453 dolphin from Brazil or: How little do we know our biodiversity. PLOS ONE 9. DOI:

454 10.1371/journal.pone.0083623.

455 Iriarte V, Marmontel M. 2013. River dolphin (Inia geoffrensis, Sotalia fluviatilis) mortality events 
456 attributed to artisanal fisheries in the western brazilian amazon. AQUATIC MAMMALS 39:116-124.

457 DOI: 10.1578/AM.39.2.2013.116.

458 Jensen FH, Rocco A, Mansur RM, Smith BD, Janik VM, Madsen PT. 2013. Clicking in shallow

459 rivers: short-range echolocation of Irrawaddy and Ganges river dolphins in a shallow, acoustically 460 complex habitat. PLOS ONE 8. DOI: 10.1371/journal.pone.0059284.

461 Kamminga C, Van Hove MT, Englesma FJ, Terry RP. 1993. Investigations on cetacean sonar X:

462 A comparative analysis of underwater echolocation clicks of Inia spp. and Sotalia spp. AQUATIC 463 MAMMALS 19:31-43.

464 Kamminga C, Wiersman H. 1981. Investigations on cetacean sonar II. Acoustical similarities and 465 differences in Odontocetes sonar signals. AQUATIC MAMMALS 8:41-62.

466 Kamminga C, Cohen Stuart A and Silber GK. 1996. Investigations on cetacean sonar XI: Intrinsic 467 comparison of the wave shapes of some members of the Phocoenidae family. AQUATIC MAMMALS 468 22:45-55.

469 Ladegaard M, Jensen FH, Beedholm K, Da Silva VMF, Madsen PT. 2017. Amazon river dolphins 470 (Inia geoffrensis) modify biosonar output level and directivity during prey interception in the wild. 471 JOURNAL OF EXPERIMENTAL BIOLOGY 220:2654-2665. DOI: 10.1242/jeb.159913.

472 Ladegaard M, Jensen FH, De Freitas M, Da Silva VMF, Madsen PT. 2015. Amazon river dolphins 473 (Inia geoffrensis) use a high-frequency short-range biosonar. JOURNAL OF EXPERIMENTAL 474 BIOLOGY 218:3091-3101. DOI: 10.1242/jeb.120501.

475 Latrubesse EMC, Sinha JSR. 2005. Tropical Rivers. GEOMORPHOLOGY 70:187-206.

476 Liaw A, Wiener M. 2002. Classification and regression by randomForest. $R$ NEWS 2:18-22.

477 Lilly JC, Miller AM. 1961. Sounds emitted by the bottlenose dolphin. SCIENCE 133:1689-1693.

478 DOI: $10.1126 /$ science.133.3465.1689. 

480 nose - convergent evolution of $130 \mathrm{khz}$ pulses in toothed whale sonars? BIOACOUSTICS 15:195481 206. DOI: 10.1080/09524622.2005.9753547.

482 May-Collado LJ, Wartzok D. 2007. The freshwater dolphin Inia geoffrensis geoffrensis produces 483 high frequency whistles. THE JOURNAL OF THE ACOUSTICAL SOCIETY OF AMERICA 484 121:1203-1212. DOI: 10.1121/1.2404918.

485 May-Collado LJ, Wartzok D. 2010. Sounds produced by the tucuxi (Sotalia fluviatilis) from the 486 Napo and Aguarico rivers of Ecuador. LATIN AMERICAN JOURNAL OF AQUATIC MAMMALS 487 8:131-136. DOI: 10.5597/lajam00162.

488 Meade R, Koehnken L. 1991. Distribution of the river dolphin, tonina Inia geoffrensis, in the 489 Orinoco River basin of Venezuela and Colombia. INTERCIENCIA 16:300-312.

490 Medina E, Silva JF. 1990. Savannas of Northern South America: A steady state regulated by 491 water-fire interactions on a background of low nutrient availability. JOURNAL OF 492 BIOGEOGRAPHY 17:403. DOI: 10.2307/2845370.

493 Melcón, ML, Failla, M, Iñíguez MA. 2012. Echolocation behavior of franciscana dolphins 494 (Pontoporia blainvillei) in the wild. THE JOURNAL OF THE ACOUSTICAL SOCIETY OF 495 AMERICA 131:EL448-EL453. DOI: 10.1121/1.4710837.

496 Melo-Santos G, Rodrigues ALF, Tardin RH, De Sá Maciel I, Marmontel M, Da Silva ML, 497 May-Collado LJ. 2019. The newly described Araguaian river dolphins, Inia araguaiaensis 498 (Cetartiodactyla, Iniidae), produce a diverse repertoire of acoustic signals. PEERJ. DOI: 499 10.7717/peerj.6670.

500 Melo-Santos G, Walmsley SF, Marmontel M, Oliveira-da-Costa M, Janik VM. 2020. Repeated 501 downsweep vocalizations of the Araguaian river dolphin, Inia araguaiaensis . THE JOURNAL OF 
502 503

504 505

\section{6}

507 508 Chicago Press, Chicago, IL.

509

Norris KS. 1968. The evolution of acoustic mechanisms in odontocete cetaceans. In: Drake ET ed.

510 Evolution and Enoironment. Yale University Press, New Haven, 297-324.

511 Norris KS. 1975. Cetacean biosonar. Part 1. Anatomical and behavioral studies. BIOCHEMICAL 512 AND BIOPHYSICAL PERSPECTIVES IN MARINE BIOLOGY 2:215-236.

513 Norris KS. Dormer KJ, Pegg J, Lifse GJ. 1971. The mechanism of sound production and air 514 recycling in porpoises: a preliminary report. PROC. CON. BIOT. SONAR DIVING MAMMALS 8:151517.

516 Paschoalini M, Almeida RM, Trujillo F, Melo-Santos G, Marmontel M, Pavanato HJ, Guerra FM, 517 Ristau N, Zerbini AN. 2020. On the brink of isolation: Population estimates of the Araguaian river 518 dolphin in a human-impacted region in Brazil. PLOS ONE 15:1-17. DOI:

519 10.1371/journal.pone.0231224.

520 Pavanato HJ, Melo-Santos G, Lima DS, Portocarrero-Aya M, Paschoalini M, Mosquera F, Trujillo 521 F, Meneses R, Marmontel M, Maretti C. 2016. Risks of dam construction for South American river 522 dolphins: A case study of the Tapajós River. ENDANGERED SPECIES RESEARCH 31:47-60. DOI: 523 10.3354/esr00751.

524 Pettena JL, Barros Almm, Matos WD, Ribeiro ACO, Carvalho RM. 1980. Estudos de Inventário 
525 Hidrelétrico na Amazônia: a Bacia do Rio Xingu. In: ABGE ed. Simpósio sobre as características

526 geológico-geotectônicas da região amazônica. 115-136.

527 Pilleri G, Gihr M. 1977. Observations on the Bolivian (Inia geoffrensis boliviensis d'Orbigny,

528 1834) and the Amazonian bufeo (Inia geoffrensis geoffrensis de Blainville, 1817) with description of

529 a new subespecies (Inia geoffrensis humboldtiana). INVESTIGATION ON CETACEA 8:11-76.

530 Podos J, Da Silva VMF, Rossi-Santos MR. 2002. Vocalizations of amazon river dolphins, Inia

531 geoffrensis: Insights into the evolutionary origins of delphinid whistles. ETHOLOGY 108:601-612.

532 DOI: $10.1046 /$ j.1439-0310.2002.00800.x.

533 R Core Team. 2015. R: a language and environment for statistical computing. $R$

534 FOUNDATION FOR STATISTICAL COMPUTING, Vienna. https:/www.r-project.org/

535 Reeves RR, Leatherwood S. 1994. Action Plan for the Conservation of Cetaceans. Gland: IUCN.

536 Reeves RR, Martin AR. 2009. River Dolphins. Encyclopedia of Marine Mammals:976-979. DOI:

537 10.1016/b978-0-.

538 Ruiz-García M, Banguera E, Cardenas H. 2006. Morphological analysis of three Inia (Cetacea:

539 Iniidae) populations from Colombia and Bolivia. ACTA THERIOLOGICA 51:411-426. DOI:

540 10.1007/BF03195188.

541 Savage KM, Potter PE. 1991. Petrology of modern sands of the rios Guaviare and Inirida, southern

542 Colombia: tropical climate and sand composition. THE JOURNAL OF GEOLOGY, 99:289-298.

543 Secretaria de planejamento e meio ambiente (Seplan), governo do Estado do Tocantins. 2001.

544 Plano de Manejo do Parque Estadual do Cantão, Palmas.

545 Secretaria de planejamento e meio ambiente (Seplan), governo do Estado do Tocantins. 2016.

546 Plano de Manejo do Parque Estadual do Cantão, Palmas.

547 Soldevilla MS, Henderson EE, Campbell GS, Wiggins SM, Hildebrand JA, Roch MA. 2008. 
548 Classification of Risso's and Pacific white-sided dolphins using spectral properties of echolocation

549 clicks. THE JOURNAL OF THE ACOUSTICAL SOCIETY OF AMERICA 124:609-624. DOI:

$55010.1121 / 1.2932059$.

551 Swets J. 2013. Measuring the accuracy of diagnostic information. MEDICAL DECISION

552 MAKING 93-142. DOI: 10.1002/9781118341544.ch5.

553 Trujillo F, Crespo E, Van Damme P., Usma JS. 2010. The action plan for South American river 554 dolphins, 2010-2020.

555 Trujillo F, Diazgranados MC, Fuentes L, Llanos Y, Martinez J, Castelblanco DN, Bermúdez

556 AL, Carrasquilla MC, Gomez JR, Rios M, Martinez AM, Álvarez-Leon R, Lacambra C, Pinilla G,

557 Maldonado J, Bravo G. 2004. Estudios de Fauna Silvestre en Ecosistemas Acuáticos em la

558 Orinoquia Colombiana. Bogotá, DC, Colombia.

559 Wagstaff K, Cardie C, Rogers S, Schrödl S. 2001. Constrained k-means clustering with

560 background knowledge. INTERNATIONAL CONFERENCE ON MACHINE LEARNING ICML 577-

561584.

562 Walker W a., Leatherwood S, Goodrich KR, Perrin WF, Stroud RK. 1986. Geographical variation

563 and biology of the Pacific white-sided dolphin, Lagenorhynchus obliquidens, in the north-eastern

564 Pacific. Research on dolphins 441-.

565 Yamamoto Y, Akamatsu T, da Silva VMF, Yoshida Y, Kohshima S. 2015. Acoustic

566 characteristics of biosonar sounds of free-ranging botos (Inia geoffrensis) and tucuxis (Sotalia

567 fluviatilis) in the Negro River, Amazon, Brazil . THE JOURNAL OF THE ACOUSTICAL SOCIETY

568 OF AMERICA 138:687-693. DOI: 10.1121/1.4926440.

569 Zimmer WMX, Madsen PT, Teloni V, Johnson MP, Tyack PL. 2005. Off-axis effects on the

570 multipulse structure of sperm whale usual clicks with implications for sound production. THE 
571 JOURNAL OF THE ACOUSTICAL SOCIETY OF AMERICA 118:3337-3345. DOI:

$57210.1121 / 1.2082707$.

573

574 
Figure 1

Study area.

The points show where the vocalizations of Inia spp. were collected. The colored lines show the course of the (1) Guaviare, (2) Madeira, (3) Xingu, and (4) Araguaia rivers, respectively.

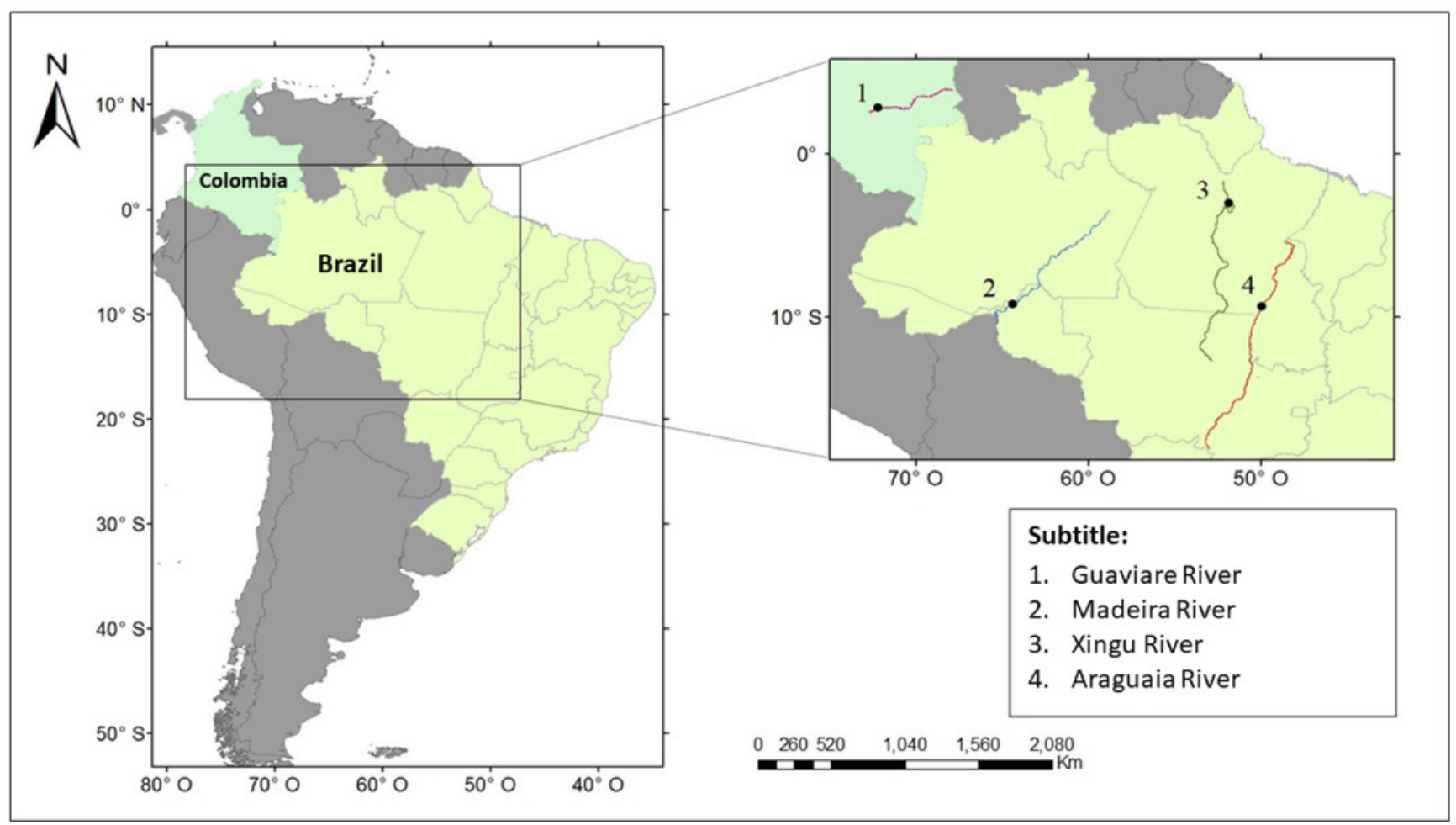


Figure 2

Echolocation click train produced by Inia sp.

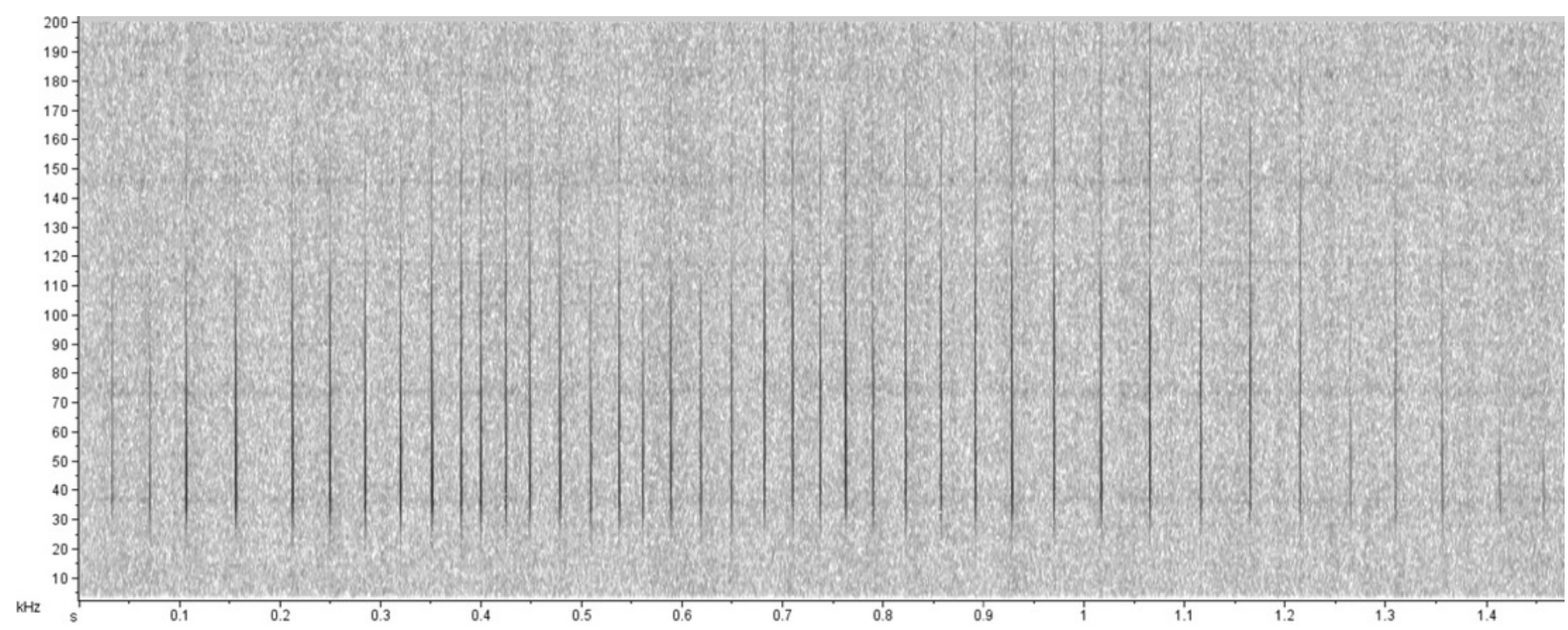


Figure 3

Differences among echolocation clicks of Inia lineages.

Ia: Inia araguaiaensis; Igg: I. geoffrensis geoffrensis; Igh: I. g. humboldtiana; Inia sp.: I.

boliviensis, I. g. geoffrensis and hydrids. (A) Fp: peak frequency; (B) BW3: 3dB bandwidth; (C) BW10: 10dB bandwidth. 
$\frac{Q}{4}$
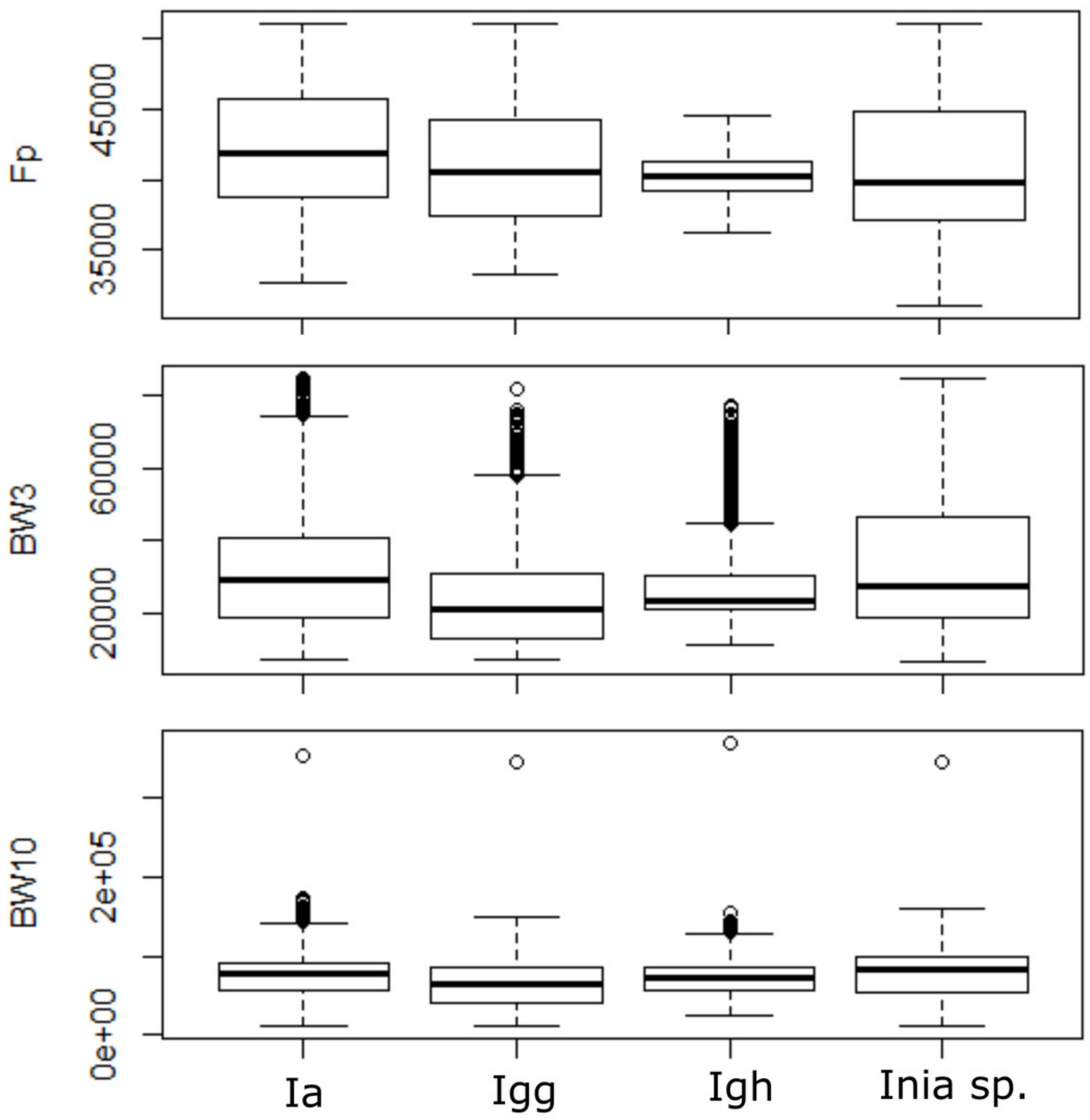


\section{Figure 4}

Outputs of the Random Forest models for the classification of the 'species' and subspecies of genus Inia according to their echolocation clicks.

la: Inia araguaiaensis; Igg: I. geoffrensis geoffrensis; Igh: I. g. humboldtiana. (A) Decision trees with an out-of-bag estimator (OOB) of 31.84\%; (B) Mean decrease accuracy and Gini variable importance measure showing the importance of each analyzed vocalization parameter (Fp: peak frequency; BW3: 3dB bandwidth BW3; BW10: 10dB bandwidth) for the model; (C) Receiver Operating Characteristic (ROC) curves: each curve represents the sorting of the efficiency of the model for the 'species' and subspecies and the area under the curve (AUC) is the indicator of the goodness of fit. 


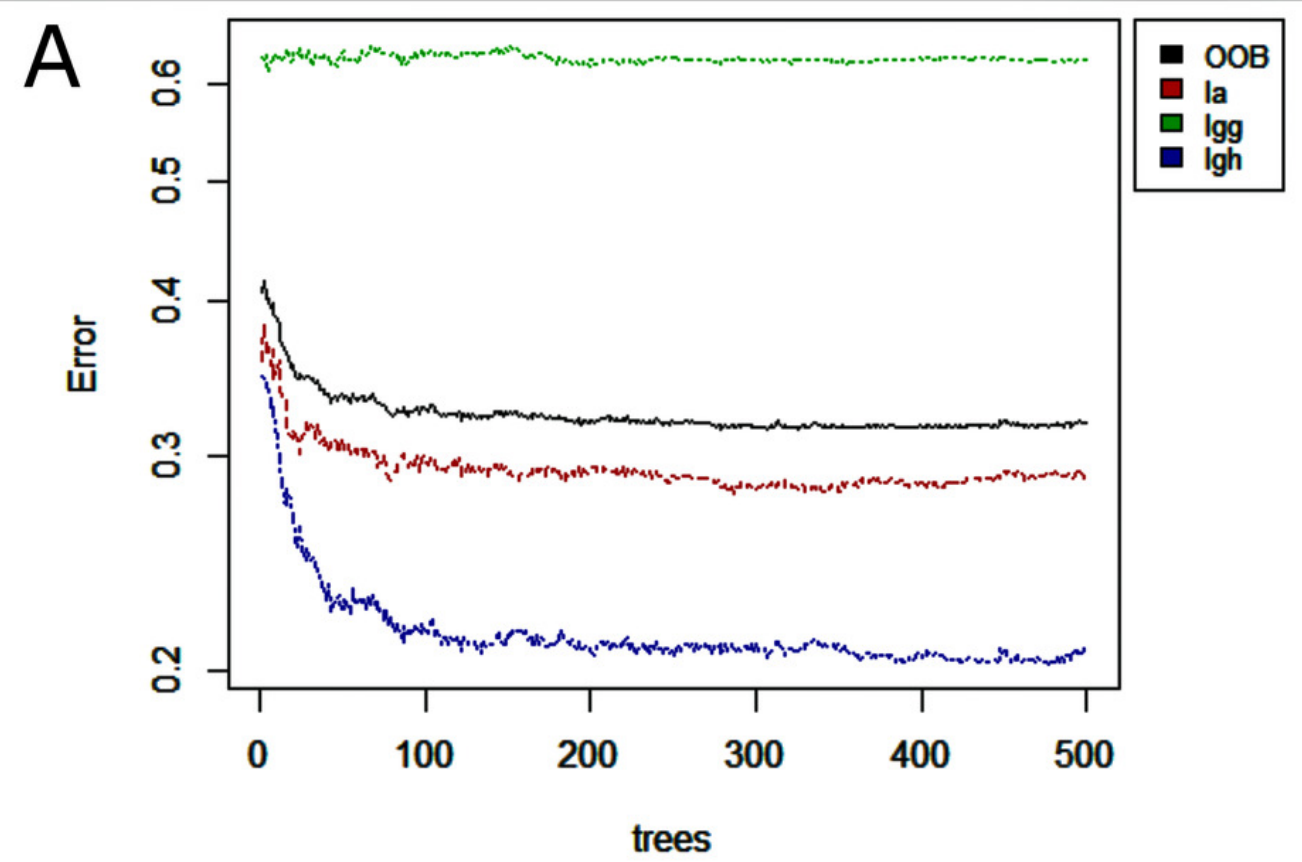

B
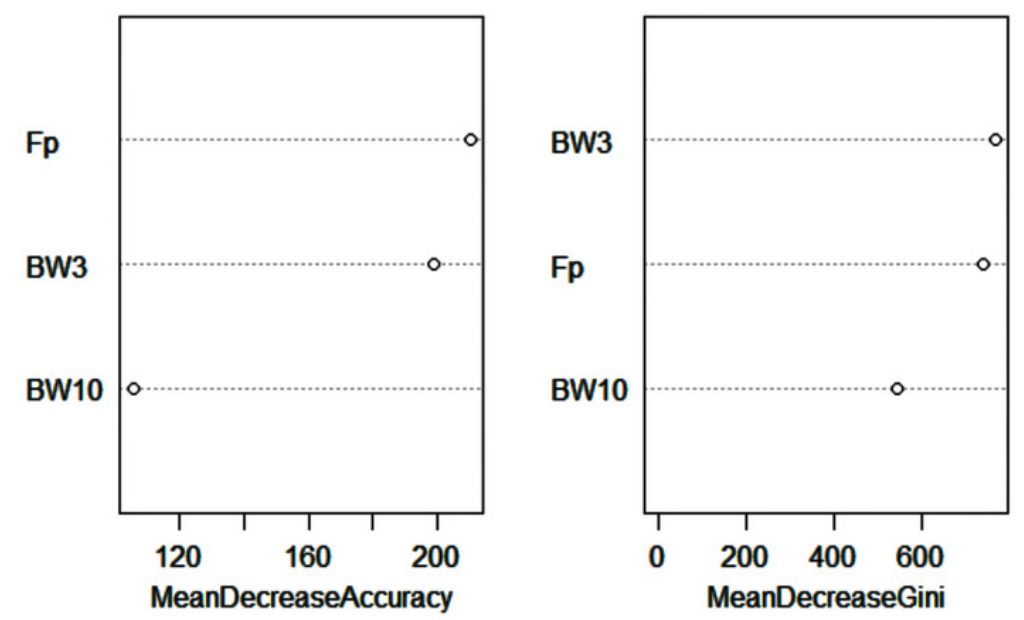

C

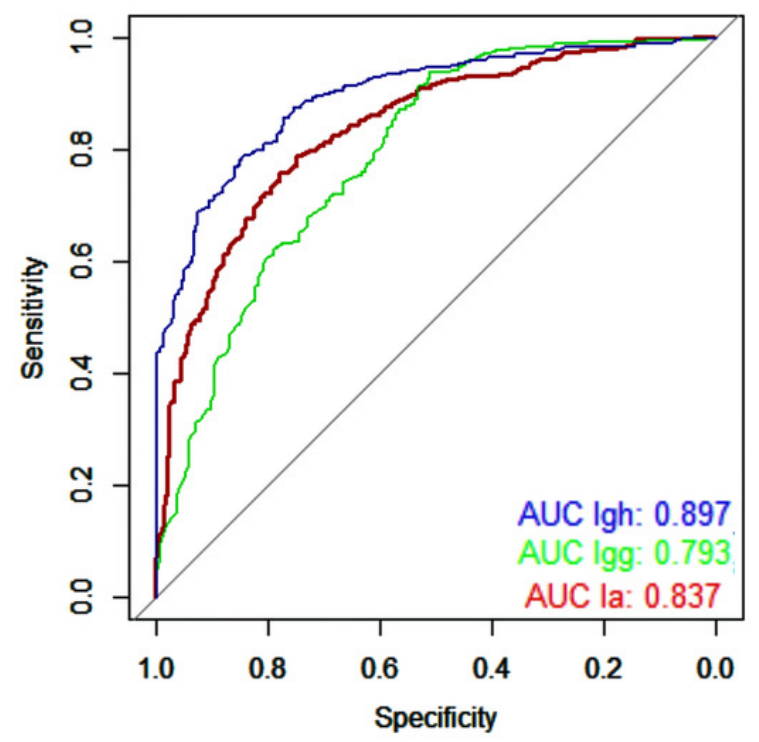


Figure 5

The k-means clustering analysis for the animals of the Madeira River (I. boliviensis, I. $g$. geoffrensis and hybrids).

It shows the silhouette with the optimal number of clusters (three) and the cluster plot of the echolocation clicks of the animals. 


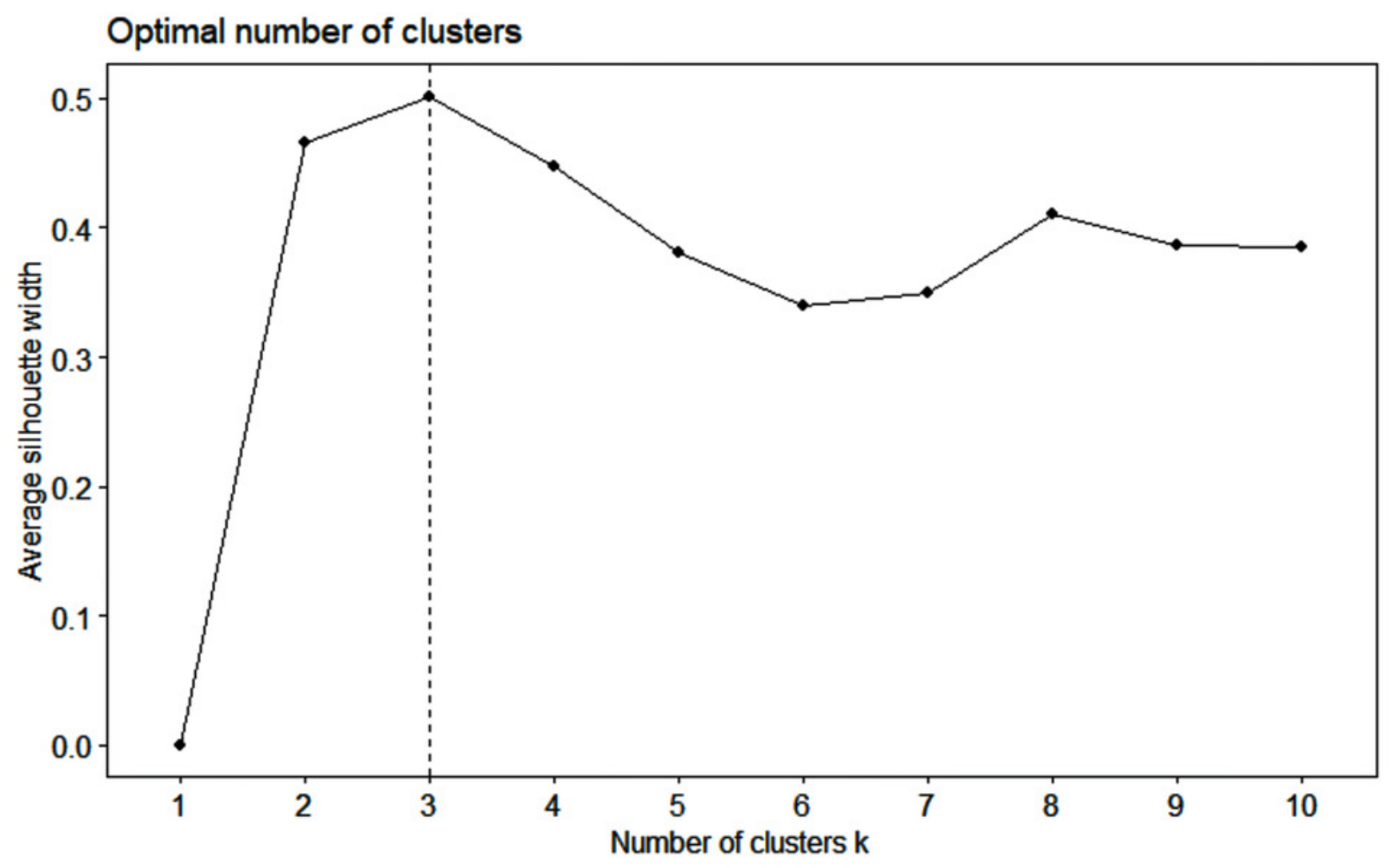

\section{Cluster plot}

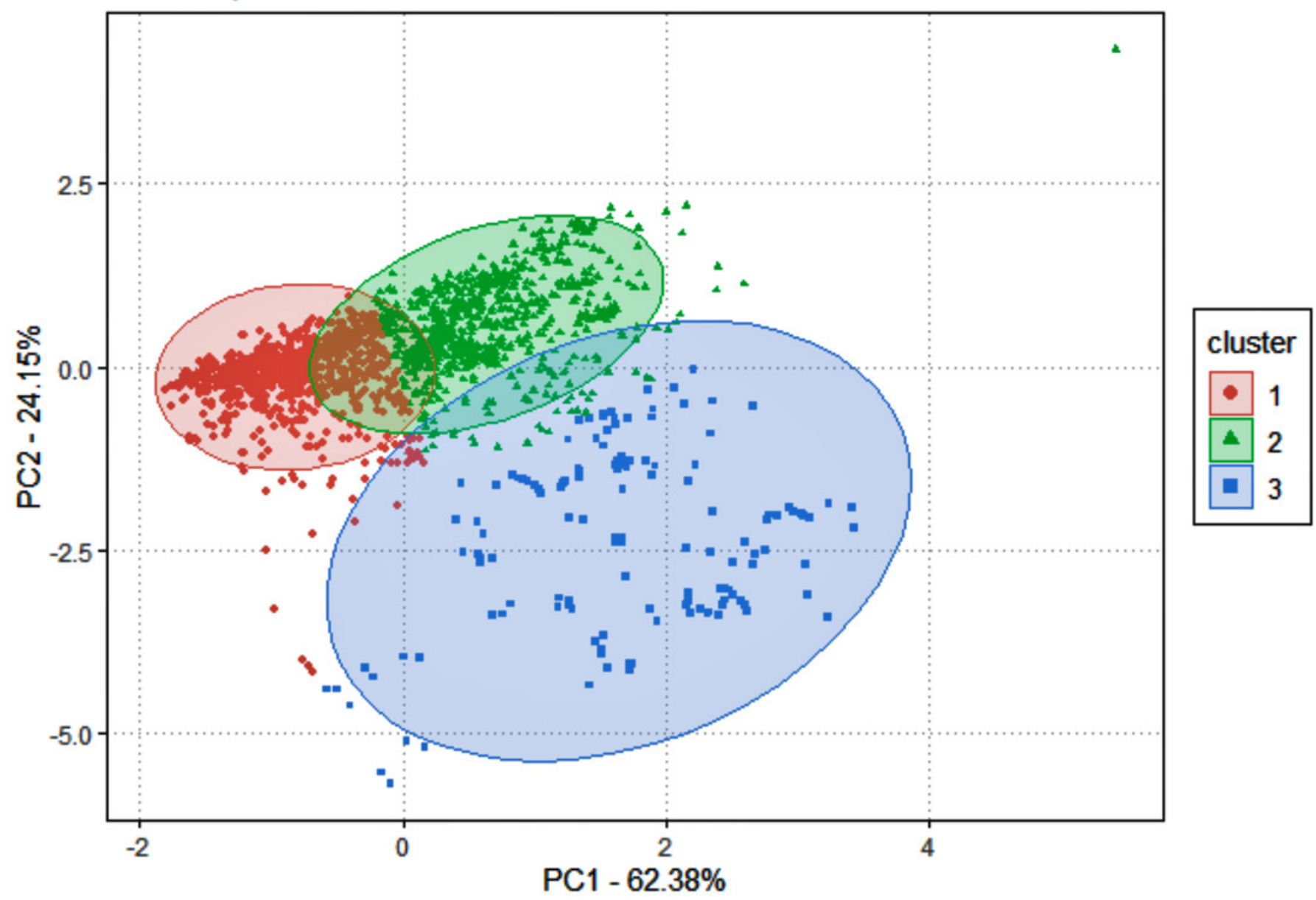




\section{Figure 6}

Outputs of the Random Forest models for the classification of the Madeira River individuals (I. boliviensis, I. g. geoffrensis and hybris) and I. g. geoffrensis (la) from Xingu River by their echolocation clicks.

Ispp1, Ispp2 and Ispp3 represents the three clusters of Madeira River individuals. (A) Decision trees with an out-of-bag estimator (OOB) of 23.41\%; (B) Mean decrease accuracy and Gini variable importance measure showing the importance of each analyzed vocalization parameter (Fp: peak frequency; BW3: 3dB bandwidth BW3; BW10: 10dB bandwidth) for the model; (C) Receiver Operating Characteristic (ROC) curves: each curve represents the sorting of the efficiency of the model for the 'species' and subspecies and the area under the curve (AUC) is the indicator of the goodness of fit. 

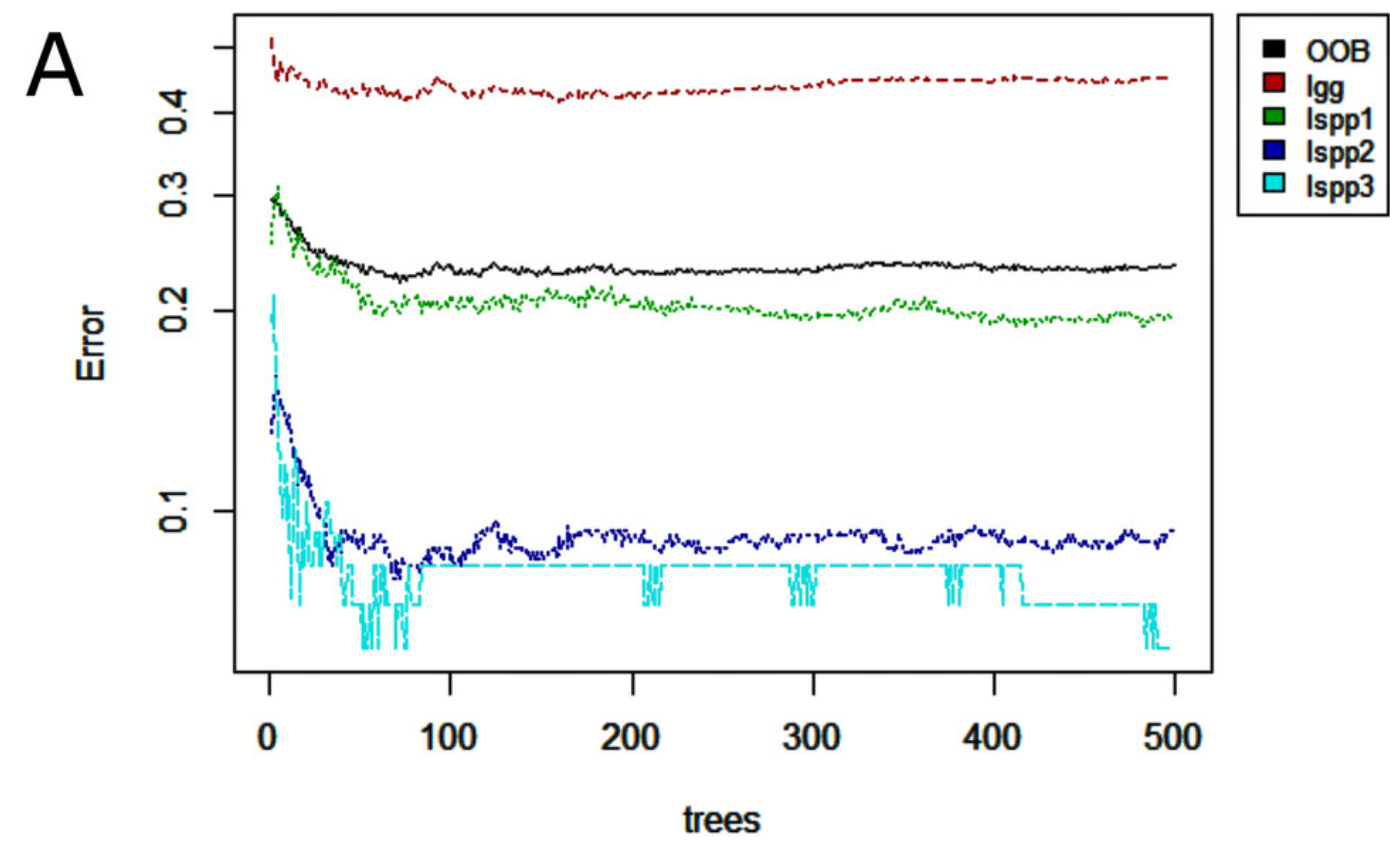

B
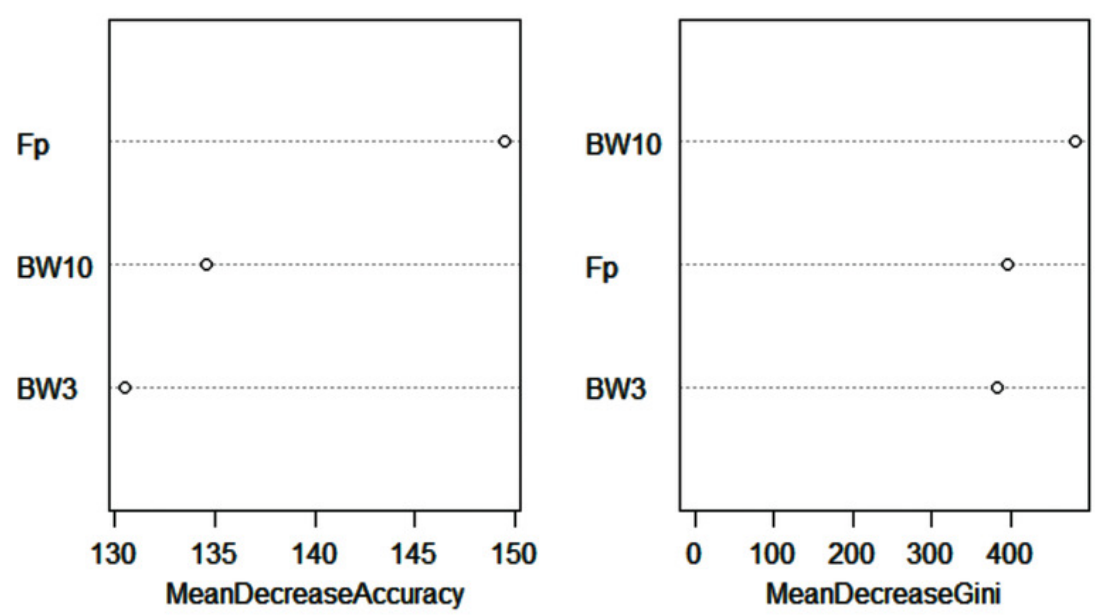

C

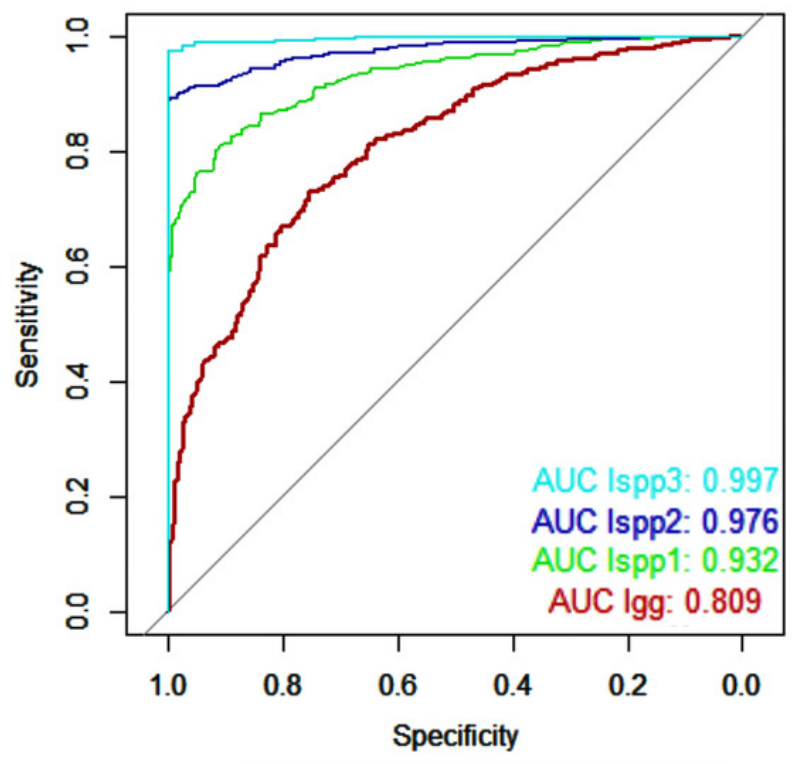




\section{Table $\mathbf{1}$ (on next page)}

Overview of data used in the analysis, including the mean number of animals in each sampled river. 
1

Table 1:

Overview of data used in the analysis, including the mean number of animals in each sampled river.

\begin{tabular}{c|c|c|c|c|c|c|c}
\hline River & $\begin{array}{c}\text { Effort } \\
\text { (days) }\end{array}$ & $\begin{array}{c}\text { Minutes } \\
\text { analyzed }\end{array}$ & $\begin{array}{c}\text { Mean } \\
\text { number of } \\
\text { animals }\end{array}$ & $\begin{array}{c}\text { Number of } \\
\text { click } \\
\text { trains }\end{array}$ & $\begin{array}{c}\text { Number of } \\
\text { clicks }\end{array}$ & $\begin{array}{c}\text { Mean } \\
\text { water } \\
\text { depth }(\mathrm{m})\end{array}$ & Water type \\
\hline Araguaia & 6 & 34 & 3.7 & 41 & 1637 & 5 & Black \\
\hline Xingu & 5 & 28 & 4.3 & 53 & 779 & 7.5 & Clear \\
\hline Guaviare & 6 & 6 & 3 & 24 & 1636 & 12 & White \\
\hline Madeira & 4 & 18 & 4.4 & 40 & 1799 & 3 & White \\
\hline Total & 21 & 86 & 3.8 & 158 & 5851 & - & - \\
\hline
\end{tabular}




\section{Table 2 (on next page)}

Descriptive statistic of echolocation clicks of the species of genus Inia.

Individuals from the Madeira River (I. boliviensis, I. g. geoffrensis and hybrids) are represented as Inia spp. The mean, standard deviation, maximum and minimum values are represented for the interclick interval (ICl), $10 \mathrm{~dB}$ bandwidth (10db BW), 3dB bandwidth (3dB $\mathrm{BW}$ ) and peak frequency (Fp). 


\section{Table 2:}

\section{Descriptive statistic of echolocation clicks of the species of genus Inia.}

Individuals from the Madeira River (I. boliviensis, I. g. geoffrensis and hybrids) are represented as Inia spp. The mean, standard deviation, maximum and minimum values, median and interquartile range are represented for the interclick interval (ICI), 10dB bandwidth (10dB BW), $3 \mathrm{~dB}$ bandwidth (3dB BW) and peak frequency $(\mathrm{Fp})$.

\begin{tabular}{|c|c|c|c|c|c|}
\hline $\begin{array}{c}\text { Species/ } \\
\text { subspecies }\end{array}$ & Value & ICI (ms) & $\begin{array}{c}10 \mathrm{~dB} \mathrm{BW} \\
(\mathrm{kHz})\end{array}$ & $\begin{array}{c}3 \mathrm{~dB} \text { BW } \\
(\mathrm{kHz})\end{array}$ & $\mathrm{Fp}(\mathrm{kHz})$ \\
\hline \multirow{4}{*}{$\begin{array}{c}\text { I. } \\
\text { araguaiaensis }\end{array}$} & mean $\pm \mathrm{sd}$ & $39.6 \pm 30.9$ & $74 \pm 27.6$ & $32.2 \pm 17.8$ & $49 \pm 12.1$ \\
\hline & $\max -\min$ & $228.3-2.0$ & $354.9-11.6$ & $84.9-7.2$ & $106-32.7$ \\
\hline & median & 30.7 & 76.8 & 29.4 & 46.2 \\
\hline & interquartile range & $23.1-43.9$ & $55.5-90.6$ & $18.5-40.1$ & $23.1-43.9$ \\
\hline \multirow{4}{*}{$\begin{array}{c}\text { I. } g . \\
\text { geoffrensis }\end{array}$} & mean \pm sd & $68.9 \pm 35.5$ & $65.5 \pm 28.8$ & $24.3 \pm 14.8$ & $45.5 \pm 9.3$ \\
\hline & $\max -\min$ & $202.1-10.2$ & $346.2-11.1$ & $81.6-7.1$ & $100.5-10.6$ \\
\hline & median & 57.6 & 63.6 & 20.9 & 42.7 \\
\hline & interquartile range & $44-84.6$ & $41.5-85.1$ & $12.6-30.8$ & $38.6-50.4$ \\
\hline \multirow{4}{*}{$\begin{array}{c}\text { I. } g . \\
\text { humboldtiana }\end{array}$} & mean \pm sd & $13.8 \pm 7.4$ & $72.7 \pm 23.6$ & $28.2 \pm 12.7$ & $44 \pm 7.3$ \\
\hline & $\max -\min$ & $96.9-2.5$ & $370.8-24.7$ & $77.1-11$ & $97.6-24.4$ \\
\hline & median & 12.4 & 72.6 & 23.6 & 41.2 \\
\hline & interquartile range & $8.6-16.9$ & $55.2-85$ & $21.1-30.5$ & $39.6-45.6$ \\
\hline \multirow{4}{*}{ Inia spp. } & mean $\pm \mathrm{sd}$ & $33.9 \pm 28.4$ & $77.6 \pm 28.9$ & $33.8 \pm 20.1$ & $45.5 \pm 12.4$ \\
\hline & $\max -\min$ & $208.6-1$ & $345.4-10.6$ & $84.5-6.4$ & $103.1-31.0$ \\
\hline & median & 24.4 & 81.7 & 27.1 & 42.1 \\
\hline & interquartile range & $16.9-38.6$ & $53.6-100$ & $18.8-46.2$ & $38-47.9$ \\
\hline
\end{tabular}

1 


\section{Table 3 (on next page)}

Discrimination of echolocation clicks parameters between 'species' and subspecies of genus Inia by Dunn-Bonferroni post hoc test.

The analyzed parameters were: peak frequency $(F p), 10 \mathrm{~dB}$ bandwidth (10dB BW) and $3 \mathrm{~dB}$ bandwidth (3dB BW). Inia spp. represents the Madeira River population (I. boliviensis, I. $g$. geoffrensis and hybrids). p-values in bold show significant differences. 
Table 3:

Discrimination of echolocation clicks parameters between lineages of genus Inia by DunnBonferroni post hoc test.

The analyzed parameters were: peak frequency (Fp), 10dB bandwidth (10dB BW) and $3 \mathrm{~dB}$ bandwidth $(3 \mathrm{~dB} \mathrm{BW})$. Inia spp. represents the Madeira River population (I. boliviensis, I. $g$. geoffrensis and hybrids). p-values in bold show significant differences.

\begin{tabular}{c|c|c|c}
\hline \multirow{2}{*}{ Parameter } & $\begin{array}{c}\text { I. araguaiaensis X } \\
\text { I. g. humboldtiana }\end{array}$ & $\begin{array}{c}\text { I. araguaiaensis X } \\
\text { Inia } \mathrm{spp} .\end{array}$ & $\begin{array}{c}\text { I. araguaiaensis X } \\
\text { I. g. geoffrensis }\end{array}$ \\
\hline Fp $(\mathrm{kHz})$ & $<\mathbf{0 . 0 0 1}$ & $<\mathbf{0 . 0 0 1}$ & $<\mathbf{0 . 0 0 1}$ \\
\hline $10 \mathrm{~dB}$ BW $(\mathrm{kHz})$ & 0.08 & $<\mathbf{0 . 0 0 1}$ & $<\mathbf{0 . 0 0 1}$ \\
\hline $3 \mathrm{~dB}$ BW $(\mathrm{kHz})$ & $<\mathbf{0 . 0 0 1}$ & 1 & $<\mathbf{0 . 0 0 1}$ \\
\hline Parameter & I. g. humboldtiana X & I. g. humboldtiana X & I. g. geoffrensis X \\
& Inia $\mathrm{spp}$. & I. g. geoffrensis & Inia spp. \\
\hline Fp $(\mathrm{kHz})$ & 1 & 0.14 & $<\mathbf{0 . 0 0 5}$ \\
\hline $10 \mathrm{~dB} \mathrm{BW}(\mathrm{kHz})$ & $<\mathbf{0 . 0 0 1}$ & $<\mathbf{0 . 0 0 1}$ & $<\mathbf{0 . 0 0 1}$ \\
\hline $3 \mathrm{~dB} \mathrm{BW}(\mathrm{kHz})$ & $<\mathbf{0 . 0 0 1}$ & $<\mathbf{0 . 0 0 1}$ & $<\mathbf{0 . 0 0 1}$ \\
\hline
\end{tabular}

1

2 


\section{Table 4(on next page)}

Confusion matrix of the Random Forest models.

It shows the correct classification of the echolocation clicks of genus Inia, as well as the misclassification. Values are shown in percentages. 
Table 4:

Confusion matrix of the Random Forest models.

It shows the correct classification of the echolocation clicks of genus Inia, as well as the misclassification. Values are shown in percentages.

\begin{tabular}{c|c|c|c}
\hline Species/subspecies & Ia & Igg & Igh \\
\hline Ia & 67 & 18 & 15 \\
\hline Igg & 23 & 68 & 9 \\
\hline Igh & 16 & 1 & 74 \\
\hline
\end{tabular}

Accuracy $=70 \%$

Ia: Inia araguaiaensis; Igg: I. g. geoffrensis; Igh: I. g. humboldtiana

\begin{tabular}{c|c|c|c|c}
\hline Species/cluster & Igg & Ispp1 & Ispp2 & Ispp3 \\
\hline Igg & 64 & 27 & 8 & 1 \\
\hline Ispp1 & 20 & 79 & 1 & 0 \\
\hline Ispp2 & 19 & 1 & 80 & 0 \\
\hline Ispp3 & 13 & 0 & 2 & 85 \\
\hline
\end{tabular}

Accuracy $=76 \%$

Igg: I. g. geoffrensis from Xingu River; Ispp1, Ispp2 and Ispp3: clusters from k-means analysis with individuals from Madeira River (I. boliviensis, I. g. geoffrensis and hybrids) 